\title{
Archiwa a chorwacka historiografia literacka. Nieznane śpiewniki kajkawskie
}

\begin{abstract}
Plejić Poje Lahorka, Archiwa a chorwacka historiografia literacka. Nieznane śpiewniki kajkawskie (Archives and the Croatian Literary Historiography. Unknown Kajkavian Songbooks). "Poznańskie Studia Slawistyczne" 19. Poznań 2020. Publishing House of the Poznań Society for the Advancement of the Arts and Sciences, Adam Mickiewicz University, pp. 135-147. ISSN 2084-3011.

Archival research is of great importance for the study of old Croatian literature, as a large part of the body of literary texts has been preserved in manuscripts to the present day, and many of them are kept in archives. Although at its beginnings Croatian national philology was strongly focused on archival work, in the $20^{\text {th }}$ century this kind of research was abandoned, despite the fact that there was still a lot of unanalyzed material left in the archives, as well as many possibilities for correction or supplementing previous conclusions. Thus the handwritten Kajkavian songbooks, especially the secular ones, have been only partially examined. In addition, some songbooks from the Croatian State Archives have never become an object of research. This article draws attention to the importance of fundamental archival research, without which it is impossible to properly draw a picture of the Kajkavian element of old Croatian literature.
\end{abstract}

KeYwords: old Kajkavian literature; secular Kajkavian songbooks; manuscripts; Croatian State Archives

Chorwackim odpowiednikiem słowa arhiv (archiwum) jest pismohrana. Drugi człon tego złożenia (-hrana) pochodzi od czasownika hraniti, który oznacza m.in. 'zachowywać, przechowywać' (współcześnie znaczenie to jest widoczne w czasowniku pohraniti). Archiwa długo postrzegano jako ,przechowalnię” materiału i nie były one szczególnie interesujące dla szerszej publiczności. Obecnie, jako instytucje zachowujące dziedzictwo, próbują stać się „widoczne”, ważne społecznie i aktywne, a ich działalność zaliczana jest do „sektora kreatywnego” (Rašić Bakarić, 2015). Widocznym znakiem otwierania się jest udział chorwackich archiwów w akcji Noc Muzeów, która co roku jest bez wątpienia najchętniej uczęszczanym 
wydarzeniem kulturalnym w kraju. Rośnie również popularność ,zarządzania dziedzictwem", heritage studies i podobnych nowych koncepcji, w których archiwa znajdują miejsce dla siebie. (Re)prezentacja archiwów w dużej mierze posługuje się też technologiami cyfrowymi, a w popularyzacji pomaga czasem przypadek. I tak, na przykład, pewien historyk z Sarajewa, badając w Dubrownickim Archiwum Państwowym kwestie związane z historią Dubrownika, w piętnastowiecznym kodeksie natrafił na niezwykłe ślady atramentu: odciski kocich łapek. Sfotografował je i opublikował na Twitterze; jego post szybko zdobył ogromną popularność (można by powiedzieć, że stał się ,wiralowym hitem”), co przyniosło odrobinę sławy również instytucji, w której przechowywany jest rękopis ${ }^{1}$. Ostatnimi czasy, ze względu na materiały archiwalne z okresu socjalizmu, chorwackie archiwa stały się (także) ważnym tematem debat politycznych ${ }^{2}$.

Współczesne teorie wskazujące na to, że archiwum nie jest wyłącznie magazynem, lecz polem działania skomplikowanych praktyk i produkcji znaczeń, mogą zostać zastosowane również w kontekście historiografii literackiej. W przypadku chorwackim są one szczególnie użyteczne w interpretacji procesów zachodzących w XIX wieku, kiedy kształtowała się tożsamość narodowa, dla której jednym z kluczowych fundamentów była literatura chorwacka sprzed odrodzenia narodowego. Innymi słowy, proces ustanawiania korpusu dawnej literatury chorwackiej był częściowo także procesem narodotwórczym. I choć niektóre archiwa ważne dla badania starszej literatury zostały założone już dawno (np. Archiwum Braci Mniejszych w Dubrowniku), to archiwa we współczesnym rozumieniu, jako instytucje nowożytnego państwa, pojawiły się dopiero w XIX wieku. Te z nich, które są interesujące z punktu widzenia literatury chorwackiej, powstały w głównej mierze wskutek archiwistycznych, kolekcjonerskich, ale też naukowych wysiłków chorwackich działaczy narodowych.

W Zagrzebiu, który w XIX wieku w całości przejmuje rolę ośrodka narodowego, pierwsze świadome próby zebrania, skatalogowania i opi-

\footnotetext{
${ }^{1}$ Więcej na ten temat np. na stronie http://www.portaloko.hr/clanak/senzacija-izdubrovnika-otisak-macje-sape-u-srednjovjekovnoj-knjizi-/0/43040/.

${ }^{2}$ Publikację poświęconą archiwom, co prawda z artykułami o nieco bardziej tradycyjnym podejściu, wydało czasopismo wydawnictwa Matica hrvatska, „Hrvatska revija” 2, 2017. W ostatnich latach chorwacka przestrzeń kulturalna była zdominowana przez duskusje nad prawem o archiwach.
} 
sania zabytków piśmiennych, zwłaszcza literackich, aby w ten sposób je udokumentować i zachować (oraz wykorzystać do tworzenia historii kultury chorwackiej) zwykle przypisuje się inicjatywie biskupa zagrzebskiego Maksimilijana Vrhovca (1752-1827). On to właśnie w 1813 roku zlecił wydrukowanie odezwy skierowanej do proboszczów swojej diecezji, w której zachęca do zbierania wszystkiego, co związane z mową „ilirską”: słownictwa, powiedzeń i przysłów, poezji ustnej, ksiąg oraz, co w tym kontekście ma szczególne znaczenie, śpiewów kościelnych i świeckich. Wezwanie to z łaciny na język chorwacki przetłumaczył i w 1837 roku ponownie opublikował Ljudevit Gaj (1809-1872). Od czasów odrodzenia narodowego to właśnie Gaj, obok Ivana Kukuljevicia Sakcinskiego (1816-1889), będzie odgrywał kluczową rolę w pozyskiwaniu i archiwizowaniu starych ksiąg i rękopisów ${ }^{3}$. Szczególnie ważne były ich podróże do Dalmacji, a zwłaszcza do Dubrownika, odbywane właśnie w celu poszukiwania dzieł dawnych pisarzy. Zgromadzone przez nich zbiory stały się podstawą dwóch ważnych archiwów: pierwszym jest Archiwum Chorwackiej Akademii Nauki i Sztuki, gdzie znaczną część zasobów stanowią rękopisy odkupione w 1868 roku od Kukuljevicia, a drugim Zbiór Rękopisów i Ksiąg Starych Biblioteki Uniwersyteckiej, który powstał w 1893 roku, gdy instytucja ta weszła w posiadanie kolekcji pozostawionej przez Ljudevita Gaja ${ }^{4}$. Rękopisy Kukuljevicia i Gaja (obok zasobów dubrownickich archiwów i bibliotek kościelnych) stały się podstawowym materiałem, który pomógł nakreślić korpus dawnej literatury chorwackiej, były także podstawą przygotowania znacznej liczby wydań krytycznych dawnych pisarzy, opublikowanych przez wówczas nowo powstałą Jugosłowiańską (dziś: Chorwacką) Akademię Nauki i Sztuki (dalej: JAZU/HAZU) ${ }^{5}$.

Z perspektywy badań nad dawną literaturą chorwacką można powiedzieć, że ostatnie dekady XIX w. były czasem gorączki archiwum (anachronicznie używając tego znanego wyrażenia), w czym szczególną rolę

\footnotetext{
${ }^{3}$ Kukuljević był także pracownikiem Archiwum Krajowego od 1848 do 1860 roku.

${ }^{4}$ Pomimo że zbiór według nomenklatury instytucjonalnej nie jest archiwum, pełni on taką funkcję i przechowuje liczne rękopisy dzieł dawnych pisarzy chorwackich, wśród których jest ponad 700 rękopisów i 16000 ksiąg Ivana Kukuljevicia.

${ }^{5}$ Były one publikowane w seriach wydawniczych Stari pisci hrvatski (od 1869 roku) i Građa za povijest književnosti hrvatske (od 1897 roku).
} 
odegrało archiwum JAZU. Zarówno prace historycznoliterackie, oparte na badaniach archiwalnych, jak i przygotowanie starych rękopisów do druku, przebiegały dość szybkim rytmem, pomimo że zadanie to było skomplikowane i wymagające, a warunki trudne. Jednakże w wieku XX, a zwłaszcza $\mathrm{w}$ jego drugiej połowie, $\mathrm{i}$ archiwalne, i tekstologiczne prace nad starymi rękopisami i księgami stopniowo spowalniały, a w końcu zamarły. Gdybyśmy zapytali, gdzie znajdujemy się dzisiaj, z całą pewnością moglibyśmy odpowiedzieć, że zbyt wcześnie odstąpiliśmy od źródeł, a zwłaszcza od rękopisów. Dotyczy to tak samo Osmana Ivana Gundulicia, dzieła należącego do kanonu literatury chorwackiej i stanowiącego fundament procesów narodotwórczych w XIX wieku, a domagającego się nowego wydania krytycznego $0^{6}$, jak i dzieł wielu znakomitych pisarzy tworzących po łacinie czy „mniejszych” chorwackich autorów, a także dawnej literatury kajkawskiej, o której będzie tu jeszcze mowa. Podczas gdy w pierwszej połowie XX wieku ważne miejsce w dyscyplinie zajmowali filolodzy, tacy jak Milan Rešetar, Franjo Fancev i Tomo Matić, w drugiej połowie stulecia zaczęły dominować różne neofilologiczne podejścia, najpierw formalistyczne, a następnie historyczno-kulturowe. Były one co prawda ważne, gdyż chorwacką naukę o literaturze, która skoncentrowała się na interpretacji, uczyniły bardziej nowoczesną, ale jednocześnie oddaliło to badaczy od analiz tekstologicznych i filologicznych w ogóle, które uważano za bardziej tradycyjne, a nawet wyczerpane, pomimo że wiele tekstów dawnej literatury chorwackiej pozostało słabo przebadanych, ich autorstwo i datacja określone w sposób budzący wątpliwości, a także nie zostały one opublikowane we współczesnych opracowaniach. Popularność bardziej nowoczesnych podejść, w połączeniu z innymi, obiektywnymi trudnościami, zaowocowała swoistą niechęcią do pracy badawczej w archiwum, a w konsekwencji także niedostatkiem nowoczesnych wydań krytycznych i ubogą tradycją tekstologiczną ${ }^{7}$.

${ }^{6}$ Więcej na ten temat w artykule Ivana Lupicia i Ireny Bratičević (2017), w którym wspomniano dawną próbę redakcji Osmana Gundulicia.

${ }^{7} \mathrm{O}$ wadze i sukcesie swoistego powrotu do fundamentalnych, a zatem i archiwalnych badań świadczą osiągnięte w ciągu ostatnich dwudziestu pięciu lat rezultaty studiów nad życiem i twórczością Marka Marulicia oraz jego kręgu kulturowego. W wielu aspektach uzupełniły, a nawet zmieniły one naszą wiedzę o splickim pisarzu (więcej informacji na ten temat w czasopiśmie „Colloquia Maruliana”). 
Dygitalizacja zbiorów archiwalnych ogromnie ułatwia dziś pracę naukową, jednak niektóre chorwackie archiwa zawierające materiały ważne dla historii literatury chorwackiej nadal pozostają zaniedbane. Na przykład bogate w rękopisy Archiwum HAZU wciąż nie posiada rzetelnego katalogu, a co dopiero możliwości wyszukiwania online. Aby w ogóle zobaczyć jego zbiory, użytkownicy muszą je odwiedzić osobiście. Katalog jest przestarzały i składa się z ręcznie zapisanych kart katalogowych niezawierających prawie żadnych informacji o rękopisie, oprócz autora, tytułu i ewentualnie wieku lub roku powstania. Z drugiej strony, jak już wspomniano, filologia narodowa także się za bardzo nie wykazała. Od lat sześćdziesiątych XX wieku do każdego rękopisu dołączona jest karteczka, na którą muszą się wpisać jego użytkownicy, każdy, kto zamówi określony rękopis, może zatem sprawdzić jego „historię użytkowania”. Te małe wykazy pokazują, że po rękopisy z zakresu dawnej literatury chorwackiej sięgali naprawdę nieliczni czytelnicy. Niektórych rękopisów nie wyjmowano z magazynu po dwadzieścia lat. Mówiąc krótko, niewiele jest rękopisów, których liczba użytkowników/czytelników przez ostatnich sześćdziesiąt lat przekroczyłaby dziesięciu.

Do niedostatecznie poznanych obszarów kroatystyki, w których powinny zostać przeprowadzone także badania archiwalne, zalicza się kajkawski człon literatury chorwackiej sprzed odrodzenia narodowego. Stopień dzisiejszego stanu przebadania kajkawskiego korpusu może zostać porównany do stopnia znajomości kanonicznej literatury dubrownickiej w połowie XIX wieku, kiedy filologia narodowa dopiero zaczynała się kształtować. Dawna literatura kajkawska była wtedy marginalizowana, ponieważ budowa nowoczesnego narodu opierała się na idiomie sztokawsko-jekawskim, na pierwszym planie znajdowała się zatem literatura dubrownicka, nie zaniedbywano również elementu sztokawsko-ikawskiego (slawońskiego i dalmatyńskiego). O ile taki stosunek do dziedzictwa kajkawskiego w XIX wieku da się wyjaśnić odrodzeniową ideologią, o tyle dziś nie ma już usprawiedliwienia dla lekceważenia tego zasobu. W korpusie tym najgorzej się ma kajkawska liryka świecka. W odróżnieniu od prozy kajkawskiej, która w większości była drukowana ${ }^{8}$, poezja liryczna, za

${ }^{8}$ Skądinąd pomyślny los kajkawskich ksiąg sprzed odrodzenia narodowego w kontekście ogólnochorwackiej produkcji księgarskiej pokrótce opisał Zoran Kravar: „Ilością 
wyjątkiem kilku pieśni okolicznościowych i śpiewników religijnych, nie była publikowana, lecz krążyła w formie rękopisów. Pisano o nich rzadko i fragmentarycznie, dlatego wiedza o dawnej liryce kajkawskiej została w dużej mierze pominięta w przeglądach historii literatury chorwackiej. Na podstawie podręczników historii literatury można by dojść do wniosku, że kajkawska liryka świecka w zasadzie nie istniała, co nie jest do końca prawdą. Aby jednak skorygować to twierdzenie, należy najpierw przeprowadzić badania archiwalne. Część z rękopiśmiennych śpiewników, które przetrwały do naszych czasów, dziś znajduje się w kolekcjach prywatnych, a część w publicznych archiwach i zbiorach archiwalnych, jednak nasza wiedza o wielkości i zasobności (zachowanego) korpusu jest wciąż niepełna. Pierwszy i dotąd jedyny spis kajkawskich śpiewników sporządził Ivan Zvonar w 1996 roku, był to katalog wystawy Kajkaviana Croatica (Zvonar, 1996), w którym zebrał i pokrótce opisał 23 śpiewniki religijne i świeckie powstałe od końca XVI wieku do chorwackiego odrodzenia narodowego. Uwadze środowiska naukowego całkowicie umknął pewien niewielki zbiór rękopiśmiennych śpiewników kajkawskich przechowywany w Chorwackim Archiwum Państwowym ${ }^{9}$. Nie wiadomo, kiedy tam trafiły: niektóre być może zostały zachowane i przekazane przez Ivana Kukuljevicia (cf. przypis 3), inne zaś zawdzięczają swoje ocalenie długoletniemu dyrektorowi Archiwum, Ivanowi Bojničiciowi ${ }^{10}$, a może też dziś mamy do nich dostęp dzięki staraniom wielkiego kolekcjonera, archiwisty, a następnie także dyrektora Archiwum, Emilija Laszowskiego, którego ex libris znajduje się na niewielkim rękopiśmiennym tomiku ze wspomnianego

drukowanych dzieł i jakością ich oprawy dawna literatura kajkawska odczuwalnie przewyższa renesansową i porenesansową literaturę wschodniego wybrzeża Adriatyku. Badacz literatury dubrownicko-dalmatyńskiej musi się przyzwyczaić do paradoksu, że wiele ważnych i niewątpliwie wpływowych dzieł Dubrowniczan i Dalmatyńczyków - np. Osman Gundulicia albo Plandovanja Bunicia - przez długi czas istniały jako rękopisy. Z kolei historia literatury kajkawskiej to historia dzieł drukowanych. Związana z życiem Kościoła dawna literatura kajkawska miała potężnego patrona, który nie tylko dobrze funkcjonował pod względem finansowym, lecz także cenił moc słowa drukowanego" (Kravar, 1993, 109). Warto dodać, że konstatacja ta jest prawdziwa wyłącznie w stosunku do prozy i niektórych narracyjnych utworów wierszowanych, podczas gdy śpiewników, zwłaszcza świeckich, nie kompilowano z zamiarem drukowania, były bowiem przeznaczone do użytku w węższych kręgach.

${ }^{9} \mathrm{Na}$ śpiewniki te zwróciła moją uwagę Jasmina Lukec, za co jej serdecznie dziękuję.

${ }^{10}$ Bojničić był dyrektorem Chorwackiego Archiwum Krajowego (dzisiejszego Chorwackiego Archiwum Państwowego) w latach 1892-1925. 
zbioru (Rękopis 182) ${ }^{11}$. Na te rękopisy zwróciła uwagę Tatjana Puškadija-Ribkin (2003), niegdysiejsza restauratorka i konserwatorka Archiwum, która zauważyła, że tylko trzy rękopisy były znane wcześniej, a o pozostałych pięciu jeszcze nic nie napisano ${ }^{12}$. Na ile mogłam stwierdzić, o tych pięciu nie wiedzieli ani Franjo Fancev, pierwszy poważany badacz literatury kajkawskiej, który w latach dwudziestych i trzydziestych ubiegłego wieku opublikował szereg ważnych studiów z tego zakresu, ani Olga Šojat, która również intensywnie zajmowała się kajkawską poezją i publikowała ją w czasopismach pod koniec lat sześćdziesiątych i w latach siedemdziesiątych, ani też Ivan Zvonar, najbardziej konsekwentny w swoich wysiłkach żyjący badacz śpiewników kajkawskich, publikujący badania na ten temat od lat dziewięćdziesiątych ${ }^{13}$. Wszyscy troje w wielu pracach podkreślali, że obowiązkiem filologii narodowej jest przebadać archiwa, ustanowić i opublikować korpus poezji kajkawskiej, aby można go było w odpowiedni sposób interpretować i kontekstualizować. Wszyscy swą pracę, z natury rzeczy, opierali na badaniach archiwalnych, studiując znane śpiewniki i wyszukując nieznane rękopisy, ale zbiegiem okoliczności do wspomnianego zbioru w Chorwackim Archiwum Państwowym nie dotarli. Biorąc pod uwagę, że korpus dawnej literatury chorwackiej ma względnie ograniczone rozmiary, naprawdę niezwykłe jest, że nadal nie został gruntownie opracowany filologicznie i historycznoliteracko.

Z jakiego powodu ważnych jest tych pięć dotąd nieznanych rękopiśmiennych śpiewników? We wspomnianym katalogu śpiewników sporządzonym przez Ivana Zvonara nie wszystkie są świeckie, a przynajmniej nie w całości, lecz zawierają pieśni religijne i świeckie. Korpus kajkawskiej

${ }^{11}$ Laszowski był asystentem Bojničicia, a dyrektorem został w 1925 roku. Możliwe, że śpiewnik nr 183, o którym jeszcze będzie mowa, został zdobyty właśnie dzięki Laszowskiemu, nie dało się jednak tego zbadać, ponieważ Chorwackie Archiwum Narodowe było nieczynne z powodu epidemii koronawirusa, a budynek w dzielnicy Gornji grad został uszkodzony w czasie trzęsienia ziemi, które miało miejsce w Zagrzebiu 22.03.2020.

${ }^{12}$ Znane rękopisy to kopia śpiewnika Horvatzke popevke svetzke (sg. 130), którą w 1814 roku sporządził Marko Mahanović (Puškadija-Ribkin, 2003, 24), śpiewnik Antuna Tomašicia (sg. 688), który opublikował Vjekoslav Noršić (1927), a także śpiewnik Cantilenae antiquae in lingua Latina, Croatica et Hungarica saeculi XVIII. Śpiewnikiem Cantilenae antiquae (nr 176) posługiwał się Franjo Kuhač (Puškadija-Ribkin, 2003, 27-28).

${ }^{13}$ Fancev rzadko notował informacje o rękopisach, tj. miejsce ich przechowywania i sygnaturę. 
liryki świeckiej sprzed odrodzenia narodowego, przynajmniej sądząc po tym, co się zachowało (a z pewnością spora część zaginęła), jest nieduży i niedostatecznie zbadany, przez co każdy nowoodnaleziony rękopis jest bezcenny. Każde nowe odkrycie, poza tym że jest wartościowe samo w sobie, przyczynia się do wyodrębnienia coraz bardziej kompletnego zestawu i rozwiązania otwartych kwestii. Na przykład, wiele śpiewników kajkawskich nie jest datowanych; nieznani są autorzy pieśni ani ich kompilatorzy, redaktorzy i skrybowie; w większości nie wiadomo też, dla kogo zostały sporządzone; relacje między pieśniami (które występują w różnych wariantach) i śpiewnikami zostały przez dyscyplinę ledwie zarysowane; związek utworów kajkawskich z łacińskimi, węgierskimi i niemieckimi, zawartymi w niektórych śpiewnikach, również nie został wyjaśniony ${ }^{14}$. Dlatego też każdy nowy śpiewnik jest potencjalnym źródłem nowych pieśni, uzupełnieniem do tej pory słabo poznanego korpusu liryki kajkawskiej i źródłem ogólnych poszlak, które mogą pomóc w ustalaniu datacji, autorstwa i rekonstrukcji całości poezji kajkawskiej i jej Sitz im Leben.

Postaram się to zobrazować na przykładzie rękopisu 183, najobszerniejszego ze wspomnianego zbioru. Jest on ciekawy również ze względu na swą objętość właśnie: w odróżnieniu od niektórych śpiewników zawierających po kilka pieśni, obejmuje 75 utworów, 52 po chorwacku (kajkawsku) i 23 po niemiecku. Spośród 52 pieśni po chorwacku około dwie trzecie zapisane są, w mniej lub bardziej zbieżnych wersjach, zarówno w śpiewniku Pjesmarica Nikole Šafrana (Archiwum Chorwackiej Akademii Nauki i Sztuki, I a 98), jak i w zbiorze Canticum cytharaedorum cytarizantium cum cytaris suis (Zbirka rukopisa i starih knjiga, Nacionalna i sveučilišna knjižnica, R 3631) ${ }^{15}$. Te dwa pisane są tą samą ręką, a pieśni uporządkowano w nich alfabetycznie (według pierwszego wersu), starannie ozdobiono inicjałami i nagłówkami pisanymi czerwonym atramentem, a także winietami,

${ }^{14}$ Dwa śpiewniki ze wspomnianego zbioru zawierają utwory w języku niemieckim (rękopis 183), łacińskim i węgierskim (wspomniana Cantilenae antiquae, $\mathrm{nr} 176$ ).

${ }^{15}$ Zbiór Šafrana zawiera 193 pieśni, spośród których 8 jest po łacinie, a 185 po chorwacku (kajkawsku). Są to przeważnie pieśni miłosne, choć jest też trochę ,żołnierskich” (,pogranicznickich”), które powstawały wśród oficerów i żołnierzy, i to oni byli ich odbiorcami; są też pieśni humorystyczne, satyryczne i myśliwskie (,jagarske”) (więcej na ten temat w: Plejić Poje, 2019). Canticum jest pod względem liczby utworów dwukrotnie mniejszym śpiewnikiem, poza tym we wszystkim innym zgodnym ze śpiewnikiem Šafrana. 
co czyni je wizualnie najbardziej atrakcyjnymi śpiewnikami kajkawskimi. Rękopis 183 nie może się z nimi mierzyć, bowiem pisany jest wyłącznie czarnym atramentem, nie widać zamysłu uporządkowania utworów, brak też spisu treści (w przeciwieństwie do Canticum), lecz mimo wszystko trud włożony w sporządzenie śpiewnika przejawia się we względnie pięknym rękopisie i w numeracji pieśni (osobno chorwackie, osobno niemieckie). Również dukt jest bardzo podobny do tego w zbiorze Šafrana i Canticum i należałoby sprawdzić, czy śpiewnika 183 nie spisał ten sam skryba. Oznaczałoby to jednocześnie, że za trzema przywołanymi śpiewnikami kryje się jakiś zbieracz czy też redaktor, który zajmował się opracowywaniem (wytwarzaniem) śpiewników w sposób systematyczny, co stanowi ciekawą informację także dla socjologii literatury. Szczególnie intrygująca jest hipoteza, że śpiewnik powstał dla konkretnej osoby, bowiem w wielu pieśniach miłosnych w miejscu żeńskiego adresata pojawia się imię Rozalija. W innych wariantach tych samych utworów imię kobiety jest pomijane: czasem ukochaną przenośnie nazywa się łabędziem, innym razem zamiast do ukochanej podmiot liryczny zwraca się do Boga. Oto dwa przykłady (drugi pochodzi ze śpiewnika Pjesmarica Nikole Šafrana), z których przytoczone zostały pierwsze strofy (transkrypcja i podkreślenia L.P.P.):

Zakaj tuguješ tak žalosno,

\section{tužna Rozalija mâ,}

prosim, poveč na ufanom

zrok žalosti gdo je tvoj

i pitajnje, tebe prosim,

za zlo vzeti ti nemoj,

zadovoljen sigdar svoj (Rękopis 183, pieśń nr 42, „Ispitivanje za dragoga drage zbog žalosti trpečega").

Zakaj spevaš tak žalostno,

tužna ptica, labud moj,

prosim, poveč na ufanom

zrok žalosti koj je tvoj,

da to pitam, $\mathrm{z}$ tebe prosim,

za zlo vzeti ti nemoj,

ar pitanje zadovolen

zrok imati mora svoj (Pjesmarica Nikole Šafrana, ,popevka” nr 149).

\section{Ah, Rozalija, sada vidim}

da moram othajati, 
ali drugač ti ne včini

da se moram spričati,

pokehdob da sad odidem,

Bože, znaš li kada dojdem,

ime vendar moram vzet (Rękopis 183, pieśń nr 37, „Othađanje od drage”).

\begin{abstract}
Ah, moj Bože, sada vidim
da moram othajati,

ali drugač ti ne včini

da se moram spričati,

pokehdob da sad odidem,

Bože znade kada dojdem,

slavu vendar moram vzeti (Pjesmarica Nikole Šafrana, ,popevka” nr 3).
\end{abstract}

Imię Rozalija pojawia się jeszcze w trzech pieśniach, których nie ma w śpiewniku Šafrana. W śpiewnikach zwykle nie umieszczano kobiecych imion. Wyjątkami są śpiewniki Anny Katarzyny Zrinskiej i Katariny Patačić, jednak one były, jak powiedzielibyśmy dzisiaj, „spersonalizowane”. W pozostałych czasem pojawia się imię Nanika, i to jako „skostniałe” zdrobnienie; o wiele częstsze jest natomiast oznaczenie $N$ (skrót od nomen), co oznacza, że można dostosować pieśń do konkretnej adresatki, czyli pozostałe śpiewniki nie są skierowane do określonej kobiety. Śpiewnik nr 183 pod tym względem odróżnia się zatem od pozostałych. W jednej z pieśni (nr 49) wspomina się też, że Rozalija pochodzi „z kapitańskiego rodu", a takie doprecyzowanie również nie jest typowe dla kajkawskich pieśni miłosnych, co dodatkowo wskazuje na to, że chodzi o konkretną kobietę. Fakt ten sam w sobie nie jest szczególnie ważny, lecz ze względu na brak informacji o kontekście, w którym funkcjonowała kajkawska liryka świecka, zidentyfikowanie adresata mogłoby stanowić krok w kierunku określenia czasu i miejsca powstania śpiewnika. Co więcej to, że w tym przypadku adresatem jest kobieta, a w pozostałych dwóch znanych przypadkach kobiety są autorkami, redaktorkami i zamawiającymi śpiewniki (Anna Katarzyna Zrinska i Katarina Patačić), może wskazywać, iż pieśni liryczne były bliższe publiczności żeńskiej (podczas gdy pieśni biesiadne - napitnice - częściej zawierają apostrofy do męskich adresatów).

${ }^{16}$ Śpiewnik Pesme horvatske Katariny Patačić przygotował do druku Alojz Jembrih (1991), a Pjesme Ane Katarine Zrinske Josip Bratulić (2014). 
W kontekście kultury rękopiśmiennych śpiewników interesujący jest jeszcze jeden szczegół. Śpiewnik 183 zawiera też pieśń pisaną kombinacją wersów po chorwacku i po niemiecku (nr 23). Utwór ten zapisany jest jeszcze tylko u Šafrana (nr 102) ${ }^{17}$. Dyglosja była typowa dla świeckiej poezji ludowej w XVIII i XIX w. i zaobserwować ją można w śpiewnikach węgierskich, niemieckich i słowackich, w chorwackich zaś albo jest ona nieobecna, albo nie zachowały się zapisy, a zatem utwór ten, zapisany w dwóch wspomnianych rękopisach, stanowi wyjątek. W połączeniu z ogromnym podobieństwem duktu obu śpiewników, unikalne występowanie w nich tych samych pieśni mogłoby także wskazywać na tego samego redaktora lub przynajmniej na przynależność śpiewników do jednego kręgu.

Niemieckie utwory w tym rękopisie zapisane są pismem gotyckim i trudno je odczytać. Dlatego należy je przetranskrybować i zbadać, czy są to pieśni powstałe na terytorium północnozachodniej Chorwacji, czy też zostały przejęte z niemieckiego, tj. austriackiego otoczenia. Dotychczasowe badania komparatystyczne wykazały pewne kontakty między literaturą chorwacką a niemiecką (np. Zvonar 2014), jednak temat ten jest dopiero rozpoczęty, a dalsze badania z pewnością mogłyby się przyczynić do lepszego zrozumienia kultury literackiej północnozachodniej Chorwacji sprzed odrodzenia narodowego. W niniejszym artykule przedstawiono kilka szczegółów dotyczących zaledwie jednego śpiewnika. Celem tej wybiórczej analizy było pokazanie, w jaki sposób odkrycie nowego rękopisu może prowadzić do formułowania nowych problemów badawczych. Stawiane pytania wiodą do nowych informacji o pojedynczych, konkretnych rękopisach; jednak dopiero synteza wiedzy o wszystkich odnalezionych tego typu dziełach pozwoli je włączyć do historii literatury północnozachodniej Chorwacji sprzed odrodzenia narodowego, która do dziś jest niekompletna. Wówczas również pojawią się nowe pytania badawcze, jak np. kwestia możliwej ciągłości pomiędzy tymi śpiewnikami a liryką z czasów odrodzenia narodowego.

${ }^{17}$ Ten sam utwór znajduje się jeszcze w Canticum (nr 47), ale w całości jest po chorwacko-kajkawsku, przez co traci swój ironiczny, ludyczny wymiar. 
Zważywszy na to, że kajkawskie śpiewniki świeckie wciąż pozostają słabo zbadane, z całą pewnością jednym z elementarnych zadań filologii chorwackiej jest powrót do archiwum i zajęcie się materiałami, których współczesne wydanie należy przygotować, a potem opisać z perspektywy historii literatury. Praca ta jest dziś w znacznej mierze ułatwiona, ponieważ można uzyskać dobrej jakości fotografie materiałów archiwalnych, a dzięki wyszukiwaniu online możliwe jest także dotarcie do wielu zagranicznych archiwów, ważnych dla podejścia komparatystycznego. W niewielkiej kulturze, takiej jak chorwacka, lekceważący stosunek do dziedzictwa rękopiśmiennego jest, delikatnie mówiąc, luksusem, na który nie możemy sobie pozwolić. Badania archiwalne owocujące odkrywaniem nieznanych i nieprzebadanych rękopisów w kolejnej fazie mogą przynieść nowe historycznoliterackie rozpoznania i w ten sposób uczynić obraz literatury chorwackiej bardziej kompletnym i zróżnicowanym. Z drugiej strony, tendencje w naukach humanistycznych i edukacji (a także strategie posiadające ramy prawne) kładą nacisk na rozwój umiejętności i kompetencji, które z tego dziedzictwa uczynią opłacalny rynkowo ,sektor kreatywny”. W tym kontekście trudno oczekiwać, że przyszli młodzi specjaliści będą ukierunkowani na zdobywanie wiedzy filologicznej, która przygotuje ich do fundamentalnych badań archiwalnych, co wzmacnia pesymistyczne prognozy o studiach nad dawną literaturą chorwacką, przechowywaną w archiwach.

Ttumaczenie Janusz Szablewski

\section{Literatura}

Csörsz, R. I. (2013). Mehrsprachigkeit in der Populären Dichtung Ungarns im 18. Jahrhundert. „Germanistische Studien” IX, s. 41-48. http://nemet.ektf.hu/files/ publ/gs_2013_csorsz_i.pdf. 26.01.2020.

Fancev, F. (1939). Hrvatska kajkavska poezija prošlih vjekova. „Ljetopis JAZU” t. 51, s. $86-105$.

Kravar, Z. (1993). Moderni stil u bezvremenoj knjizi (Barokni elementi u pjesmarici Citara Octochorda). W: Dani Hvarskog kazališta, t. 19: Hrvatsko kajkavsko pjesništvo do preporoda. Red. N. Batušić et al. Zagreb-Split: Književni krug, s. 106-115. Lupić, I. Bratičević, I. (2017). ,Jaoh, a sada sve je inako”: o kritičkoj izdaji Gundulićeva Osmana. „Colloquia Maruliana” 26, s. 89-155. 
Noršić, V. (1927). Još jedna kajkavska pjesmarica. „Građa za povijest književnosti hrvatske" t. 10, s. 163-172.

Plejić Poje, L. (2019). „,Kam, Jožek, putuješ”. Mali prilog proučavanju stare kajkavske svjetovne lirike. „Croatica et Slavica Iadertina” 15/1, s. 145-155.

Puškadija Ribkin, T. (2003). Nekoliko manje poznatih hrvatskokajkavskih pjesmarica s kraja 18. i početka 19. stoljeća. „Kaj” XXXVI, nr 3, s. 22-30.

Rašić Bakarić, I., Bačić, K., Božić, Lj. (2015). Mapiranje kreativnih i kulturnih industrija u Republici Hrvatskoj. Projektna studija. Zagreb: Ekonomski institut.

Šojat, O. (1968a). Stara hrvatska kajkavska poezija. „Republika” 8-9, s. 458-471.

Šojat, O. (1968b). Izbor iz Ludbreške pjesmarice. „Kaj” 7-8, s. 62-72.

Šojat, O. (1973). Prekomurska pjesmarica I. Uz izbor. „Forum” 7-8, s. 176-213. https://doi.org/10.1177/001458587300700428.

Šojat, O. (1977a). Pregled hrvatske kajkavske književnosti od polovine 16. do polovine 19. stoljeća i jezično-grafijska borba uoči i za vrijeme ilirizma. W: Hrvatski kajkavski pisci, t. 1: Druga polovina 16. stoljeća. Red. K. Spoljar. Zagreb: Matica hrvatska, s. 7-69.

Šojat, O. (red.) (1977b). Hrvatski kajkavski pisci, t. 1: Druga polovina 16. stoljeća; t. 2: 17. stoljeće. Zagreb: Matica hrvatska.

Šrepel, O. (1899). Kajkavska pjesmarica, „Građa za povijest književnosti hrvatske” t. 2, s. 187-212.

Zvonar, I. (2001). Kajkavska svjetovna poezija od prvih tragova do Ignaca Kristijanovića. „Radovi Zavoda za znanstveni rad Varaždin” nr 12-13, s. 245-259.

Zvonar, I. (1994). Kajkavska lirika do preporoda u službenim povijestima hrvatske književnosti i u stvarnosti. W: Tu u provinciji. Zrinski. Čakovec: Matitca hrvatska, s. $191-216$.

Zvonar, I. (1996). Kajkaviana Croatica. Hrvatska kajkavska riječ [katalog wystawy]. Zagreb: Muzej za umjetnost i obrt, s. 285-315.

Zvonar, I. (2014). Pregled povijesti kajkavske usmene književnosti, t. 1: Od prvih tragova do dvadesetih godina 20. stoljeća. Martinišće-Zabok: Hrvatska udruga Muži zagorskoga srca.

Zvonar, I. (2016). Pregled povijesti kajkavske usmene književnosti, t. 2: Vinko Žganec i njegovo doba. Martinišće-Zabok: Hrvatska udruga Muži zagorskoga srca. 